\title{
MANAGEMENT OF ENDOCRINE DISEASE Clinical management of paragangliomas
}

\author{
Eleonora P Corssmit and Johannes A Romijn ${ }^{1}$ \\ Department of Endocrinology, Leiden University Medical Center, PO Box 9600, 2300 RC Leiden, \\ The Netherlands and ${ }^{1}$ Department and Division of Medicine, Academic Medical Center, \\ University of Amsterdam, Amsterdam, The Netherlands
}

\begin{abstract}
Paragangliomas (PGLs) are rare vascular, neuroendocrine tumors of paraganglia, which are associated with either sympathetic tissue in adrenal (pheochromocytomas (PCCS)) and extraadrenal (sympathetic paraganglioma (sPGLs)) locations or parasympathetic tissue of the head and neck paragangliomas (HNPGLs). As HNPGLs are usually benign and most tumors grow slowly, a wait-and-scan policy is often advised. However, their location in the close proximity to cranial nerves and vasculature may result in considerable morbidity due to compression or infiltration of the adjacent structures, necessitating balanced decisions between a wait-and-see policy and active treatment. The main treatment options for HNPGL are surgery and radiotherapy. In contrast to HNPGLs, the majority of SPGL/PCCs produces catecholamines, in advanced cases resulting in typical symptoms and signs such as palpitations, headache, diaphoresis, and hypertension. The state-of-the-art diagnosis and localization of sPGL/PCCs are based on measurement of plasma and/or 24-h urinary excretion of (fractionated) metanephrines and methoxytyramine (MT). SPGL/PCCs can subsequently be localized by anatomical (computed tomography and/or magnetic resonance imaging) and functional imaging studies $\left({ }^{123}\right.$ I-metaiodobenzylguanidine-scintigraphy, ${ }^{111}$ In-pentetreotide scintigraphy, or positron emission tomography with radiolabeled dopamine or dihydroxyphenylalanine). Although most PGL/PCCs are benign, factors such as genetic background, tumor size, tumor location, and high MT levels are associated with higher rates of metastatic disease. Surgery is the only curative treatment. Treatment options for patients with metastatic disease are limited. PGL/PCCS have a strong genetic background, with at least one-third of all cases linked with germline mutations in 11 susceptibility genes. As genetic testing becomes more widely available, the diagnosis of PGL/PCCs will be made earlier due to routine screening of at-risk patients. Early detection of a familial PGL allows early detection of potentially malignant PGLs and early surgical treatment, reducing the complication rates of this operation.
\end{abstract}

Invited Authors' profile

Johannes (Hans) A Romijn is Professor of Medicine and Chairman of the Division of Medicine, Academic Medical Center, University of Amsterdam, The Netherlands. Prof. Romijn trained in internal medicine in the Academic Medical Center, University of Amsterdam. In 1997 he was appointed as Professor in Clinical Nutrition and in 1998 as Professor of Endocrinology and Chairman of the Department of Endocrinology, Leiden University Medical Center (LUMC). He served as president of the Dutch Endocrine Society from 2002-2006. In 2010 he was appointed chairman of the Division and the Department of Medicine of the Amsterdam Medical Centre (AMC). His research focuses on pathophysiology and treatment of pituitary diseases and of diabetes.

Eleonora Corssmit graduated in Medicine from the University of Amsterdam and the Academic Medical Centre, Amsterdam, The Netherlands. She is currently an Assistant Professor at the Department of Medicine, Section of Endocrinology, at the Leiden University Medical Centre in Leiden, the Netherlands. Her clinical and scientific work is focussed on adrenal tumors, especially pheochromocytoma and paraganglioma.

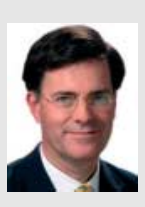

(๑) 2014 European Society of Endocrinology Printed in Great Britain
Published by Bioscientifica Ltd. 


\section{Introduction}

Paragangliomas (PGLs) are rare vascular, neuroendocrine tumors of paraganglia cell clusters originating from the neural crest that have co-migrated with the autonomic nervous system (1). PGLs are associated with either the sympathetic tissue in adrenal (pheochromocytomas (PCCs)) and extra-adrenal locations (sympathetic PGLs (sPGLs)) or the parasympathetic tissue of the head and neck paragangliomas (HNPGL, formerly called glomus tumors) (1). PGLs can be found from the skull base to the sacrum. From all PGLs, PCCs have the highest relative incidence. In 340 unselected PGL patients, about $73 \%$ of the patients had PCC, $9 \%$ had sPGL, and 20\% had HNPGL $(2,3)$. HNPGLs have a predilection for the middle ear (tympanic PGL), the dome of the internal jugular vein (jugular PGL), the bifurcation of the common carotid arteries (carotid body PGL), or along the vagal nerve (vagal PGL), sPGL for the mediastinum (from the thoracic sympathetic chain) and the abdominal and pelvic para-aortic regions, including the organ of Zuckerkandl.

The prevalence of PGL is unknown but has been estimated to lie between 1:6500 and 1:2500 in the USA (4). Their prevalence is higher in autopsy series (1:2000), suggesting that many tumors remain undetected (5). The annual incidence has been reported to be two to ten cases per million (6). In hypertensive patients, sPGL/PCCs are found in $0.1-0.6 \%$, in adrenal incidentalomas in about $5 \%$ (7). PGLs may occur in all ages, with the highest incidence between 40 and 50 years and with an approximately equal sex distribution $(3,8)$. At least one-third of PGL/PCCs is hereditary, and this percentage is likely to increase with the discovery of new susceptibility genes (9). Most PGL/PCCs are benign, 10-15\% are malignant, defined by the presence of metastatic spread in sites where chromaffin tissue is normally absent, such as lymph nodes, liver, bone, and lungs $(10,11)$.

\section{Clinical picture}

\section{Sympathetic PGL/PCC}

The majority of sPGL/PCCs produces catecholamines, in advanced cases causing symptoms of catecholamine excess. In unselected series, $10-15 \%$ of cases are asymptomatic. The clinical presentation is variable due to different profiles of catecholamines secreted, presentation of symptoms related to tumor mass or other organ involvement in syndromic forms, and desensitization of adrenoreceptors (most likely due to long-term exposure to high circulating catecholamine levels) (12). Therefore, sPGL/PCC is also called the great masquerader'. Hypertension, continuous or paroxysmal, is the most common feature of advanced PCCs and sPGLs. Typical symptoms are paroxysms of severe headache, palpitations, and diaphoresis, 'the classic triad'. Paroxysms can last minutes to hours, vary in interval and occur spontaneously or be triggered by direct stimulation of the tumor (e.g. micturition in case of bladder localization), physical activity, diagnostic procedures, or certain drugs (e.g. metoclopramide, glucagon, and glucocorticoids) $(13,14)$. Other symptoms may include anxiety, nausea, vomiting, and weakness (15). In addition, hyperglycemia, resulting from metabolic actions of catecholamines, may be the presenting symptom (16). As symptoms and signs are usually atypical, a long delay in diagnosis is not uncommon. Because this can lead to severe and potentially fatal cardiovascular complications (e.g. sudden death, myocardial infarction, heart failure, and cerebrovascular accidents), a prompt diagnosis is warranted.

\section{Head and neck paraganglioma}

HNPGLs, which belong to the domain of the ear nose throat doctor, usually grow slowly. Nonetheless, patients with HNPGLs need to be checked by endocrinologists, because some of these tumors produce catecholamines and some of these patients have an increased risk to develop sPGL/PCCs. The majority of HNPGLs has a tumor doubling time of more than 10 years (17). Because of this slow growth rate, HNPGLs may remain clinically silent for years. Although these tumors are usually benign and only a minority (20-30\%) produces catecholamines, predominantly methoxytyramine (MT) $(18,19)$, their location in the close proximity of nerves and vascular structures often results in considerable morbidity due to compression or infiltration of the adjacent structures, causing symptoms such as hearing loss, tinnitus, dysphagia, and cranial nerve palsy. Carotid body tumors are the most common HNPGL, usually presenting as a painless cervical mass (20). Large compressive tumors may result in cranial nerve paralysis. Vagal body tumors present as painless neck masses, located behind the angle of the mandible, occasionally accompanied by dysphagia and hoarseness (21). Tympanic and jugular foramen tumors most commonly present as a vascular middle ear mass causing pulsatile tinnitus and 
hearing loss. Difficulties in speech, swallowing, and airway function may be the result of dysfunction of cranial nerves traversing the jugular foramen (22).

\section{Making a diagnosis by biochemical evaluation and imaging}

\section{Sympathetic PGL/PCC}

Clinical suspicion of sPGL/PCCs or the presence of an adrenal incidentaloma should be followed by biochemical testing to rule out the potentially lethal diagnosis of a sPGL/PCC. The biochemical diagnosis of sPGL/PCCs consists of the demonstration of hypersecretion of catecholamines (epinephrine, norepinephrine, and dopamine (DA)) or their $\mathrm{O}$-methylated metabolites metanephrine $(\mathrm{MN})$, normetanephrine (NMN), and MT (23). Since MNs have a longer half-life and are produced continuously within tumor cells, being the catecholamines converted to MNs by the high methyltransferase activity of chromaffin tissue, while catecholamines are intermittently secreted, measurement of plasma free MNs and/or 24-h urinary excretion of fractionated MNs provides the best test with an excellent sensitivity of $>96 \%$ for detecting sPGL/PCCs (24). Since dietary constituents (especially caffeine, nicotine, and amine-rich foods) or medication (especially antihypertensive and tricyclic antidepressant medication) can interfere with the analysis of or increase plasma levels and urinary excretion of catecholamines or its metabolites, ideally collection is performed while abstaining from these substances and/or stopping antihypertensive drugs or changing medication to the $\alpha$ blocker doxazosin $(25,26)$. In addition, plasma should be sampled after fasting and in the supine position for $30 \mathrm{~min}$, to minimize sympathoadrenal activation $(13,27,28)$. Restriction of amine-rich foods is mainly necessary for the measurement of MT (29). With regard to stopping or changing medication, which is often difficult, a reasonable alternative is not to do this and repeat testing in case of elevated results. In case of only mildly elevated values, false-positive results are usually reflected by larger increments in catecholamines as compared with MNs due to sympathoadrenal activation (30). In case plasma NMN is mildly increased, a clonidine suppression test may be useful to rule out sympathetic activation as the underlying cause, since values will normalize in case of sympathetic activation, but decrease $<40 \% 3 \mathrm{~h}$ after administration of clonidine in case of a PGL (sensitivity 100\% and specificity 96\%) (31).
PGLs exhibit different biochemical properties as PCCs mainly produce epinephrine and norepinephrine, sPGLs norepinephrine and malignant PLGs norepinephrine, DA or no catecholamines due to a dedifferentiation of the enzymatic machinery $(31,32)$. Plasma levels of chromogranin A (CgA), secreted from neurosecretory vesicles along with catecholamines (33), are often elevated in both functioning and silent PGLs and particularly in malignant ones (34). CgA levels correlate with tumor mass, making it a useful tumor marker (35). Sensitivity for identifying PGLs is 83-89\%. False-positive results, however, occur often due to liver or kidney failure or use of proton pump inhibitors (36).

After establishing a biochemical diagnosis, sPGL/PCC can be localized and staged by anatomical and functional imaging studies. Anatomical imaging such as computed tomography (CT) or magnetic resonance imaging (MRI) have an excellent sensitivity (77-98 and 90-100\% respectively) but lack specificity (29-92 and 50-100\% respectively) for detecting PCC/sPGLs $(37,38)$. On CT, PCCs usually present as homogenous tumors with soft tissue density of more than 10 Hounsfield Units and uniform enhancement with contrast. However, larger PCCs may undergo hemorrhage and necrosis resulting in areas of low density (39). On MRI, PCCs present as a mass absent of fat on chemical shift, with a high signal on $\mathrm{T} 2$ sequences as a result of their hypervascularity (40). Tumors detected by anatomical imaging can subsequently be identified as PGL by functional imaging agents that specifically target the catecholamine synthesis, storage, and secretion pathway of chromaffin cells. ${ }^{123} \mathrm{I}$ - or ${ }^{131} \mathrm{I}$-metaiodobenzylguanidine (MIBG) scintigraphy is the most widely available and used nuclear technique in the first-line functional imaging of PGL. MIBG has chemical similarities to NE and is taken up by the human NE transporter, which is expressed in most chromaffin cells and is normally responsible for catecholamine uptake (41). The sensitivity (83-100\% for ${ }^{123}$ I-MIBG and $77-90 \%$ for ${ }^{131}$ I-MIBG respectively) and specificity (95-100\% for both ${ }^{123} \mathrm{I}$ - and $\left.{ }^{131} \mathrm{I}-\mathrm{MIBG}\right)$ are high for primary tumors, being higher for PCCs than for PGLs $(42,43,44)$; however sensitivity of MIBG-scintigraphy for metastasis is relatively poor $(56-83 \%)(37,45,46,47)$. In patients with negative MIBG-scintigraphy, other tracers may be used. Radiolabeled DA or dihydroxyphenylalanine (DOPA) may be used as tracers in positron emission tomography (PET) imaging. ${ }^{18}$ F-DOPA PET has been confirmed to be useful in the evaluation of sPGL and HNPGL (48) (Fig. 1). For patients suspect for metastatic PGL, ${ }^{18}$ F-fluoro-2-deoxyglucose (FDG) PET is recommended (sensitivity $74-100 \%)(26,48,49,50)$, with the highest performance for metastatic succinate 
sensitivity for the detection of HNPGL (Fig. 1) (48), and can be adviced as the first-line imaging method for HNPGLs; if unavailable, ${ }^{18}$ F-FDG or somatostatin receptor scintigraphy can be used complementary to anatomic imaging studies (50).

\section{Management}
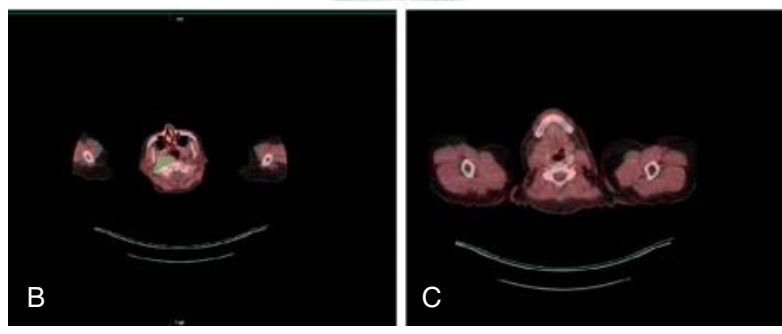

\section{Sympathetic PGL/PCC}

The treatment of choice for PCCs and sPGLs is surgical resection, preferably laparoscopically (54), but in case of a large tumor (in general $>6 \mathrm{~cm}$ ) with a higher risk of malignancy, conventional laparotomy should be considered. In order to minimize surgical complications (hypertensive crisis and arrhythmias), adequate pretreat-

\section{Figure 1}

${ }^{18} \mathrm{~F}$-DOPA PET scan of a patient with a right-sided vagal body tumor (VBT) and a small left-sided carotid body tumor (CBT):

(A) ${ }^{18}$ F-DOPA PET total body scan showing physiological uptake in the brain, heart, bile ducts and urinary tract, and pathological uptake in the HNPGLs. (B) Fusion scan of ${ }^{18} \mathrm{~F}$-DOPA PET scan with low-dose CT-scan, showing right-sided VBT. (C) Fusion scan of ${ }^{18} \mathrm{~F}$-DOPA PET scan with low-dose CT-scan, showing left-sided CBT.

dehydrogenase B (SDHB)-related PCC/PGL (50). In addition, ${ }^{111}$ In-pentetreotide scintigraphy may be useful in detecting MIBG-negative metastases (37). ${ }^{123} \mathrm{I}$-MIBG scintigraphy is widely available, with a performance similar to PET scanning using ${ }^{18} \mathrm{~F}$-fluorodopamine, ${ }^{18} \mathrm{~F}$ DOPA, and ${ }^{18}$ F-FDG for PCC $(26,47)$, for PGL, or metastatic PCC/PGL. ${ }^{123}$ I-MIBG scanning is inferior to ${ }^{18} \mathrm{~F}$-FDG PET, ${ }^{18} \mathrm{~F}$-DOPA PET or somatostatin receptor imaging with ${ }^{111}$ In-pentreotide scintigraphy $(26,49,50)$.

\section{Head and neck paraganglioma}

MRI with pre- and post-contrast enhanced 3D time of flight MR angiography sequence represents the most important imaging technique for evaluation and characterization of HNPGLs (51). MRI of HNPGL provides more diagnostic information than does CT scanning, because of the better soft tissue contrasts as compared with CT (52). MRI enables multiplanar imaging of tumor extension and vessel encasement. Ultrasound has a limited diagnostic yield, but can be of use in imaging HNPGL (53). ${ }^{123}$ I-MIBG scintigraphy has a low sensitivity for the detection of HNPGLs. ${ }^{111}$ In-pentetreotide scintigraphy was shown to have a better sensitivity, lower than that of MRI. ${ }^{18} \mathrm{~F}$-DOPA PET was shown to have a very good ment is necessary, consisting of $\alpha$-blockade (doxazosin and phenoxybenzamin) titrated at orthostatic hypotension, if needed followed by addition of $\beta$-blockade (propanolol and atenolol), especially in case of tachycardia. The day before surgery, volume expansion of intravascular volume should be started by infusion of isotonic saline as these patients are in a constant status of volume depletion (55). Pretreatment reduces perioperative mortality to below 1\% (56). Intraoperatively, hypertensive episodes are related with catecholamine release, mostly by direct manipulation of the tumor. In patients with bilateral PCC, laparoscopic cortical sparing adrenalectomy may be considered to avoid chronic glucocorticoid deficiency (57). Preoperative injection of ${ }^{123}$ I-MIBG in combination with intraoperative use of a gamma probe may localize small lesions that are difficult to find $(58,59)$.

Postoperatively, severe hypotension can occur in case of hypovolemia, which is no longer opposed by catecholamine-induced intense vasoconstriction, and prolonged effects of the preoperatively started medication ( $\alpha$-blockers). In addition, hypoglycemia can occur due to the sudden decrease in catecholamines and thereby increase in insulin secretion. Two to four weeks postoperatively, plasma and/or urinary $\mathrm{MN}$ levels should be checked, and normalization indicates successful resection of the tumor. Usually blood pressure normalizes after the operation, depending on completeness of the resection, duration of pre-existing hypertension, and potentially coexisting other causes of hypertension. Since histology cannot differentiate between benign and malignant PGL/PCC and there is the possibility of recurrence of PCC, lifelong follow-up is advised for local recurrence and metastases (26). Postoperative follow-up with annual measurement of blood pressure and plasma and/or urinary MN levels is 
advised in all patients previously treated for sPGL/PCC, with additional anatomical imaging if indicated (Fig. 2).

\section{Head and neck paraganglioma}

Treatment for HNPGL must be considered in relation to tumor growth velocity, biological activity of the tumor, patient age and medical condition, tumor size and site, and potential for treatment-related morbidity (17). As most tumors grow slowly, a wait-and-scan strategy is often advised (17). However, although HNPGLs are indolent tumors, tumor growth may lead to serious morbidity and cranial nerve impairment due to their location in close proximity to important neurovascular structures. The main treatment modalities for HNPGL are surgery and radiotherapy. A multidisciplinary team approach is recommended for the choice of treatment of most HNPGL except for the very small and easy-to-resect tumors. With surgery, it is possible to remove the tumor without recurrence. The rate of surgical complications rises with the size of the tumor (60). The most common complications are cranial nerve damage and vascular complications $(61,62,63,64,65,66)$. Although Power et al. (67) showed that preoperative embolization simplified the conduct of the operation and reduced blood loss, it did not impact on cranial nerve damage. Coexisting sPGL/PCC should be resected before resection of a HNPGL. External beam radiotherapy and radiosurgery are alternative treatment modalities for HNPGL patients, resulting in local tumor control in 79-100\%, and sometimes regression by producing fibrosis and vascular sclerosis (68). These may be first-line therapeutic strategies in patients with large growing tumors, in which resection may result in considerable morbidity, or after incomplete resection of tumor with intracranial or skull base invasion (68). The optimal choice of treatment is not clear at the moment, due to the absence of trials, selection bias, and differently defined criteria for surgery vs radiotherapy. Although some groups also propagate routine use of radiotherapy $(64,65)$, we advocate a wait-and-scan strategy, with intervention in case of tumor progression or concern about malignancy. Preoperatively and preradiotherapy, patients with HNPGL should be tested for MN excretion, and pharmacological preparation should

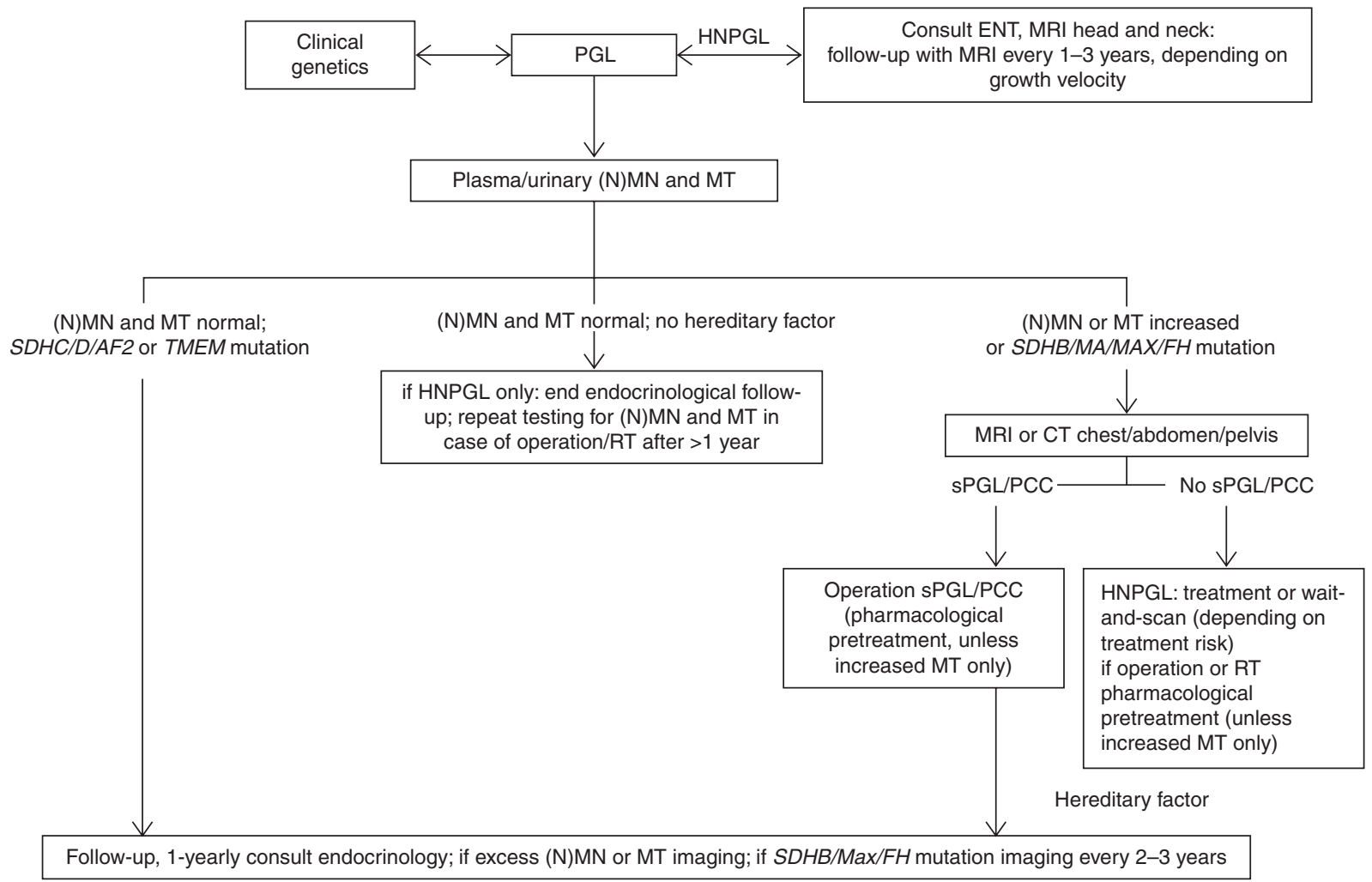

Figure 2

Stepwise approach for endocrine diagnosis, treatment, and follow-up in (hereditary) HNPGL/sPGL/PCC. 
be started in positive cases $(26,66)$, with the exclusion of patients with solitary elevation of MT. In case of increased DA secretion, there is no certainty for a benefit of pre-operative pharmacological treatment. After successful resection of a solitary, nonhereditary biochemically silent HNPGL, patient can be discharged from further follow-up. In other cases, follow-up is advised, consisting of evaluation of catecholamine excess in biochemically active HNPGLs and ENT examination and MRI of the head and neck.

\section{Malignant PGL}

There is no definite histological rule that can be used for the diagnosis of malignant PGL $(69,70)$. Therefore, malignancy is defined by the presence of metastases: tumor spread to sites where chromaffin tissue is normally absent $(10,11)$. Nearly $10 \%$ of PCCs and $10-20 \%$ of sPGLs are malignant (71), whereas HNPGLs are usually benign (72).

Malignant HNPGLs usually present with local metastases in cervical lymph nodes or systemic metastases, usually to bones, lung, and liver $(69,70,72)$, and occur most frequently in patients with $S D H B$ gene mutations (73, 74, 75). In patients with SDHD gene mutations, malignant HNPGLs are rare $(76,77)$. The primary management of patients with malignant HNPGLs should be directed toward complete surgical resection of the primary tumor and regional lymph nodes. Postoperative radiation may be beneficial in slowing the progression of residual disease (72).

Malignant sPGL/PCCs are especially associated with $S D H B$, Myc-associated factor $\mathrm{X}(M A X)$, and fumarate hydratase $(F H)$ mutations $(78,79)$. There is no effective treatment for malignant sPGL/PCCs. Although debulking of tumor is not evidence based, it may reduce catecholamine-related problems and improve response to further treatment. Up to $60 \%$ of malignant sPGL/PCCs show positive MIBG-uptake (80). After resection of ${ }^{123}$ I-MIBGpositive malignant PGL, postoperative ${ }^{131} \mathrm{I}$-MIBG treatment for consolidation has been recommended (81). However, considering the frequently encountered longterm stable disease, or very slow progression, and the absence of curative options for metastasized PGL patients, the benefits and side effects of therapeutic interventions should be carefully weighed.

The timing to systemic therapy in these patients has become the subject of debate because, a recent retrospective study in therapy-naïve patients with malignant PGL/PCC has shown that nearly half of patients achieved stable disease at 1 year and that therefore, in symptom-free patients, a wait-and-scan surveillance policy until imaging proof of progression, preferably by Response Evaluation Criteria in Solid Tumors (RECIST), seems appropriate as first-line treatment (82). A recent systematic review and meta-analysis in MIBG-positive cases have shown that treatment with therapeutic doses of ${ }^{131}$ I-MIBG resulted in an objective tumor response in 30\% of patients and stabilization of disease in $57 \%$ of patients $(81,83)$, and an objective hormonal response in $50 \%$ of patients. However, as most studies included patients irrespective of evidence of progressive disease, it cannot be ruled out that stable disease was not merely a therapy effect, but also a reflection of the natural course of the disease. MIBGnegative patients might be treated with combination chemotherapy, of which combination of cyclophosphamide, vincristine, and dacarbazine, the so-called CVD protocol, is the most effective regimen, producing predominantly partial remissions without significant change in overall survival $(84,85)$. In recent years, treatment with radiolabeled somatostatin analogs such as ${ }^{90}$ Y-DOTATOC and ${ }^{177}$ Lu-DOTATOC has also shown its credits in a limited number of patients; Forrer et al. (86) reported 13 stable diseases, two mixed responses, and six patients, which remained progressive after treatment of 28 somatostatin receptor-positive patients with metastatic PCC/PGL with DOTATOC, without severe toxicity. In addition, targeted therapies have been introduced in the battle against malignant PCC/PGL, of which especially sunitinib, an oral tyrosine kinase inhibitor, was promising in small series (87). Data from a single open-label phase II trial are currently underway (estimated study completion date: December 2013; Clinicaltrials.gov). Other palliative treatment options are conventional radiotherapy for painful bone metastases and arterial embolization, chemoembolization, or radiofrequency ablation for liver metastases $(88,89)$. Catecholamine synthesis inhibitors ( $\alpha$-methyl-para-tyrosine) or $\alpha$-receptor blockers are useful in reducing catecholamine-related symptoms and signs. Although prognosis in individuals with metastasized PGL cannot be predicted, overall survival is poor with 5-year survival rates of only $20-50 \%(90,91)$.

\section{Hereditary SPGL/PCC}

PGLs can occur either sporadically or hereditary, as part of a familial syndrome (55). Inherited disease can be suspected in case of familial antecedents of the disease, multiple primary tumors in the same individual and early age of onset, whereas sporadic PGLs are usually diagnosed in patients older than $40-50$ years (92). Until 2000, only 
Table 1 Genotype-phenotype correlations in hereditary PCC/PGL.

\begin{tabular}{|c|c|c|}
\hline Syndrome & Gene & HNPGL \\
\hline MEN2 & $R E T$ & Extremely rare \\
\hline VHL & $V H L$ & Rare \\
\hline NF1 & $N F 1$ & - \\
\hline PGL1 & $S D H D$ & +++ \\
\hline PGL2 & SDHAF2 & +++ \\
\hline PGL3 & SDHC & ++ \\
\hline PGL4 & $S D H B$ & ++ \\
\hline PGL5 & SDHA & + \\
\hline- & TMEM127 & $+I-$ \\
\hline- & $M A X$ & - \\
\hline- & $\mathrm{FH}$ & + \\
\hline
\end{tabular}

\begin{tabular}{|c|c|c|}
\hline SPGL & PCC & $\begin{array}{l}\text { Multiple } \\
\text { PGL }\end{array}$ \\
\hline- & ++ & - \\
\hline+ & ++ & + \\
\hline- & + & - \\
\hline++ & + & +++ \\
\hline- & & ++ \\
\hline+ & $+I-$ & + \\
\hline+++ & ++ & ++ \\
\hline+ & - & - \\
\hline$+1-$ & +++ & $+I-$ \\
\hline- & ++ & - \\
\hline++ & ++ & ++ \\
\hline
\end{tabular}

\begin{tabular}{l} 
Bilateral \\
PCC \\
\hline++ \\
++ \\
- \\
+ \\
- \\
- \\
+ \\
- \\
++ \\
++ \\
+
\end{tabular}

\begin{tabular}{l} 
Malignancy \\
risk \\
\hline+ /- \\
+ \\
+ \\
+ \\
$?$ \\
+ /- \\
++ \\
$?$ \\
+ \\
$++?$ \\
$++?$
\end{tabular}

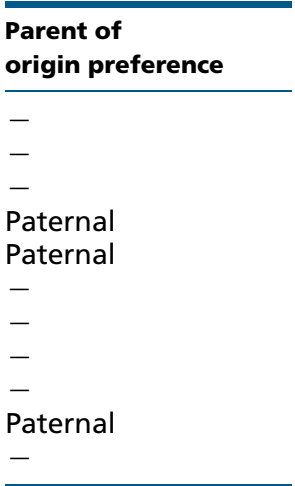

+, present; -, absent; HNPGL, head and neck paraganglioma; sPGL, sympathetic paraganglioma; PCC, pheochromocytoma; PGL, paraganglioma; MEN2, multiple endocrine neoplasia type 2; VHL, von Hippel-Lindau disease; NF1, neurofibromatosis type 1; PGL1-5, familial paraganglioma syndrome type 1-5; $S D H$, succinate dehydrogenase; SDHAF2, succinate dehydrogenase complex assembly factor 2; TMEM127, transmembrane protein 127; MAX, Myc-associated factor $\mathrm{X} ; \mathrm{FH}$, fumarate hydratase.

10\% of PGLs were associated with hereditary syndromes: von Hippel-Lindau (VHL) disease, multiple endocrine neoplasia type 2, and neurofibromatosis type 1 (NF1), resulting from respectively a germ-line mutation in tumor suppressor gene VHL (93), proto-oncogene RET $(94,95)$, and tumor suppressor gene NF1 (96). PGLs occurring in these syndromes are predominantly (bilateral) PCCs. In the last decade, it has become apparent that about $35 \%$ of the apparently sporadic PGLs are due to a germ-line mutation in one of 11 susceptibility genes (97). In addition to the above-mentioned germ-line mutations in $V H L, R E T$, and NF1, germ-line mutations have been found in one of the four subunits (A, B, C, and D) of the $S D H$ gene $(98,99$, $100,101)$, succinate dehydrogenase complex assembly factor 2 (SDHAF2), which is responsible for the flavination of the SDHA subunit (102), transmembrane protein 127 (TMEM127) (103), MAX (78), and the recently discovered FH (104). Germ-line mutations in SDHA, SDHB, SDHC, $S D H D$, and $S D H A F 2$ genes are responsible for the occurrence of syndromes named PGL5, PGL4, PGL3, PGL1, and PGL2 respectively. Germ-line mutations in SDHA and $C$ are associated with HNPGL and SPGL, SDHAF2 mutations with HNPGL, SDHD and $B$ with HNPGL, sPGLs and PCC, and TMEM127 and MAX with PCCs (9) (Table 1). SDHB mutations are generally associated with a higher malignancy rate than mutations in the other SDHx genes. Recent reviews and a metaanalysis of studies involving $S D H B$ mutated patients have documented that $17-31 \%$ of their tumors were malignant (79, 105). MAX and FH mutations have also been associated with malignant tumors $(78,104)$, although data are scarce and involve predominantly index cases.
In addition, germline and/or somatic mutations were reported in EGLN1/prolyl hydroxylase 2 (PHD2) (106), KIF1 $\beta$ (107), IDH1 (108), and hypoxia-induced factor 2 alpha (HIF2 $\alpha$ ) (109), however, only in a few patients, needing validation in larger series (26). Besides abovementioned hereditary syndromes, a small fraction of PGLs is associated with other syndromes, including Carney triad and Carney-Stratakis syndrome) (110). In addition, other tumors have been documented in SDH mutations, such as gastrointestinal stromal tumors (111), renal cell carcinomas (112), and a growth hormone-producing pituitary adenoma (113). Apart from RET, which is a protooncogene, all the other susceptibility genes for PCC/PGL are tumor suppressor genes.

\section{Hereditary factors and tumorigenesis}

PGLs can be divided in two main clusters linked to two different signaling pathways (114). Cluster 1 contains all $V H L$ - and $S D H x$-related tumors and is characterized by activation of the hypoxia-angiogenesis pathway in normoxia (115). Consistent with Knudson's two-hit hypothesis for tumorigenesis involving in a tumor suppressor gene, a heterozygous germ-line mutation in an SDHx gene is usually associated with somatic loss of the nonmutant allele in the tumor, i.e. loss of heterozygosity. This results in inactivation of SDH enzymatic activity and thereby in accumulation of succinate, which acts as an inhibitor of PHD enzymatic activity. PHDs are enzymes that are required for the degradation of HIF. As a consequence, even in the presence of oxygen, HIF cannot be destroyed via proteasome-mediated degradation driven 
by VHL protein and is stabilized to induce angiogenesis and tumorigenesis $(116,117)$. The latter also happens in VHL mutations. Interestingly, Letouzé et al. (118) have recently described a hypermethylator phenotype in SDH-related PGLs. These tumors accumulate succinate, which inhibits 2-oxoglutarate-dependent histone and DNA demethylase enzymes, resulting in epigenetic silencing, thereby affecting neuroendocrine differentiation. Cluster 2 contains all RET-, NF1-, TMEM127-, and $M A X$-mutated tumors and is associated with abnormal activation of kinase signaling pathways, such as RAS/RAF/ MAPK and PI3K/AKT/mTOR, resulting in abnormal cell growth and diminished apoptosis capacity (78, 103, 119, $120,121,122)$. The knowledge of molecular defects in PGLs can be used for development of new effective moleculartargeted therapies.

\section{Genetic testing in PGL/PCC patients and surveillance in mutation carriers}

To date, 11 susceptibility PGL genes have been identified. Consequently, the initial $10 \%$ of cases classified as genetically determined has increased to $\sim 35 \%$. This percentage is likely to increase, as there are still young patients (with a higher likelihood of a mutation) being classified as sporadic, and patients from PGL families where no mutation is found in one of the 11 susceptibility genes. All familial PGL syndromes have an autosomal-dominant mode of inheritance; interestingly, SDHD, SDHAF2, and $M A X$ are characterized by maternal imprinting, which means paternal transmission only of the disease $(9,123$, $124,125)$. Up till now, the exact molecular mechanism of maternal imprinting is unknown (126). Because of this phenomenon and incomplete penetrance, especially in $S D H B$ mutation carriers (127), many $S D H$ mutation carriers have an apparently sporadic presentation. Therefore, a negative family history does not exclude an underlying $S D H$ mutation. At present, it is advised to consider genetic testing for an underlying mutation in all PGL/PCC patients, regardless of age and family history (128). Genetic testing algorithms can be made to reduce time and costs. A positive family history for a specific mutation, country of origin, syndromic features, biochemical profile, localization, benign or malignant presentation, and $S D H B$ and SDHA immunohistochemistry of the tumor tissue (129, 130) may be valuable tools to guide the order of genetic testing (79). In case of HNPGL, SDHB, $C$, and $D$ may be tested first, if negative, $S D H A, A F 2$, and $V H L$; in case of concurrent HNPGL and sPGL/PCC SDHB and $D$, if negative $V H L$; in case of PCC RET, VHL, SDHB, D, if negative TMEM and MAX; and in case of malignant sPGL/PCC SDHB and $M A X$, if negative $S D H D$ and $V H L$. While the majority of patients undergoing SDH mutation analysis will carry missense and nonsense mutations, point mutationnegative patients who carry whole-gene or exon deletions can represent a substantial proportion of all mutations in PGL patient groups. Therefore, deletion screening by multiplex ligation-dependent probe amplification gene deletion analysis should be seriously considered as a follow-up to sequencing in all point mutation-negative patients (131). In the past years, next-generation sequencing (NGS), DNA-sequencing technologies based on massive parallel sequencing, was developed for the genetic screening of PCC/PGL. Although transition to NGS appears inevitable, allowing more rapid and cost-effective mutation detection (132), NGS based screening is still an evolving area with technical limitations, resulting from the presence of pseudogenes or repetitive regions that may result in mapping and alignment errors, to overcome (133).

The finding of a germline mutation in a patient allows for predictive testing of potentially unaffected family members, to be performed in the setting of genetic counseling in an experienced center. Genetic testing can be of great importance for patients and their relatives because it gives the opportunity for early diagnosis in family members of the affected individual (134). Early detection of a familial PGL allows early detection and early treatment with fewer complications of potentially malignant PGLs, especially in SDHB, MAX, and $F H$ mutation carriers $(135,136)$. However, because up till now only scarce information have been available on age-related penetrance in $S D H x_{-}, M A X-$, TMEM-, and $\mathrm{FH}$-related disease in asymptomatic mutation carriers, genetic testing of family members and subsequent surveillance of mutation carriers remain controversial, especially because tumor screening may cause a significant psychological burden (137). However, with the present nonevidence based knowledge, we recommend regular clinical follow-up in mutation positive carriers $(76,92)$, except for the children of female mutation carriers of $S D H D, S D H A F 2$, and $M A X$, because of maternal imprinting. Although there is currently no international consensus regarding follow-up programs, annual biochemical testing, e.g. plasma free MNs and/or urine fractionated MNs, and radiological imaging of neck and/or thorax/abdomen/pelvis every 2-3 years, depending on the mutation, with additional functional imaging in selected cases can be recommended as a surveillance program $(76,138)$ (Fig. 2). In case of 'benign' mutations, 
such as SDHD, it can be argued that annual biochemical testing followed by radiological imaging only in case of positive screening is sufficient.

\section{Future perspectives}

In the near future, NGS technology is likely to replace conventional sequencing methods, using a stepwise procedure for genetic screening. In addition, new PCC/PGL susceptibility genes are likely to be discovered by whole-genome sequencing. Therapy for malignant/ metastatic PCC/PGL is far from satisfying. Continued advances in basic science, diagnostic methods, and imaging techniques will lead to a better understanding of the pathogenesis of these diseases and by unravelling the specific genetic alterations of various PCC/PGL, new molecular targeted therapies will appear as the most promising strategies for the management of patients with metastatic PCC/PGL.

\section{Declaration of interest}

The authors declare that there is no conflict of interest that could be perceived as prejudicing the impartiality of the review.

\section{Funding}

This review did not receive any specific grant from any funding agency in the public, commercial or not-for-profit sector.

\section{References}

1 De Lellis RA, Lloyd RV, Heitz PU \& Eng C. World Health Organization Classification of Tumours. Pathology and Genetics of Tumours of Endocrine Organs. pp 57-66. Lyon: IARC Press, 2004.

2 Pacak K, Keiser H \& Eisenhofer G. Pheochromocytoma. In Textbook of Endocrinology, 5th edn, pp 2501-2534. Eds LS DeGroot \& JL Jameson. Philadelphia: Elsevier Saunders, Inc., 2005.

3 Mannelli M, Castellano M, Schiavi F, Filetti S, Giacchè M, Mori L, Pignataro V, Bernini G, Giachè V, Bacca $A$ et al. Clinically guided genetic screening in a large cohort of Italian patients with pheochromocytomas and/or functional or nonfunctional paragangliomas. Journal of Clinical Endocrinology and Metabolism 200994 1541-1547. (doi:10.1210/jc.2008-2419)

4 Chen H, Sippel RS, O'Dorisio MS, Vinik AI, Lloyd RV \& Pacak K. The North American Neuroendocrine Tumor Society consensus guideline for the diagnosis and management of neuroendocrine tumors: pheochromocytoma, paraganglioma, and medullary thyroid cancer. Pancreas 201039 775-783. (doi:10.1097/MPA.0b013e3181ebb4f0)

5 McNeil AR, Blok BH, Koelmeyer TD, Burke MP \& Hilton JM. Phaeochromocytomas discovered during coronial autopsies in Sydney, Melbourne and Auckland. Australian and New Zealand Journal of Medicine 200030 648-652. (doi:10.1111/j.1445-5994.2000. tb04358.x)
6 Beard CM, Sheps SG, Kurland LT, Carney JA \& Lie JT. Occurrence of pheochromocytoma in Rochester, Minnesota, 1950 through 1979. Mayo Clinic Proceedings 198358 802-804.

7 Lenders JW, Eisenhofer G, Mannelli M \& Pacak K. Phaeochromocytoma. Lancet 2005366 665-675. (doi:10.1016/S0140-6736(05)67139-5)

8 Cascón A, Pita G, Burnichon N, Landa I, López-Jiménez E, MonteroConde C, Leskelä S, Leandro-García LJ, Letón R, Rodríguez-Antona C et al. Genetics of pheochromocytoma and paraganglioma in Spanish patients. Journal of Clinical Endocrinology and Metabolism 200994 1701-1705. (doi:10.1210/jc.2008-2756)

9 Gimenez-Roqueplo AP, Dahia PL \& Robledo M. An update on the genetics of paraganglioma, pheochromocytoma, and associated hereditary syndromes. Hormone and Metabolic Research 201244 328-333. (doi:10.1055/s-0031-1301302)

10 Granger JK \& Houn HY. Head and neck paragangliomas: a clinicopathologic study with DNA flow cytometric analysis. Southern Medical Journal 199083 111407-111412. (doi:10.1097/00007611199012000-00010)

11 Scholz T, Schulz C, Klose S \& Lehnert H. Diagnostic management of benign and malignant pheochromocytoma. Experimental and Clinical Endocrinology \& Diabetes 2007115 155-159. (doi:10.1055/s-2007970410)

12 Bravo EL. Evolving concepts in the pathophysiology, diagnosis, and treatment of pheochromocytoma. Endocrine Reviews 199415 356-368. (doi:10.1210/edrv-15-3-356)

13 Neary NM, King KS \& Pacak K. Drugs and pheochromocytoma - don't be fooled by every elevated metanephrine. New England Journal of Medicine 2011364 2268-2270. (doi:10.1056/NEJMc1101502)

14 Rosas AL, Kasperlik-Zaluska AA, Papierska L, Bass BL, Pacak K \& Eisenhofer G. Pheochromocytoma crisis induced by glucocorticoids: a report of four cases and review of the literature. European Journal of Endocrinology 2008158 423-429. (doi:10.1530/EJE-07-0778)

15 Kebebew E \& Duh QY. Benign and malignant pheochromocytoma: diagnosis, treatment, and follow-up. Surgical Oncology Clinics of North America 19987 765-789.

16 La Batide-Alanore A, Chatellier G \& Plouin PF. Diabetes as a marker of pheochromocytoma in hypertensive patients. Journal of Hypertension 200321 1703-1707. (doi:10.1097/00004872-200309000-00020)

17 Jansen JC, van den Berg R, Kuiper A, van der Mey AG, Zwinderman AH $\&$ Cornelisse CJ. Estimation of growth rate in patients with head and neck paragangliomas influences the treatment proposal. Cancer 2000 88 2811-2816. (doi:10.1002/1097-0142(20000615)88:12<2811::AIDCNCR21>3.0.CO;2-7)

18 van Duinen N, Steenvoorden D, Kema IP, Jansen JC, Vriends AH, Bayley JP, Smit JW, Romijn JA \& Corssmit EP. Increased urinary excretion of 3-methoxytyramine in patients with head and neck paragangliomas. Journal of Clinical Endocrinology and Metabolism 2010 95 209-214. (doi:10.1210/jc.2009-1632)

19 van Duinen N, Corssmit EP, de Jong WH, Brookman D, Kema IP \& Romijn JA. Plasma levels of free metanephrines and 3-methoxytyramine indicate a higher number of biochemically active HNPGL than 24-h urinary excretion rates of catecholamines and metabolites. European Journal of Endocrinology 2013169 377-382. (doi:10.1530/EJE-13-0529)

20 Gardner P, Dalsing M, Weisberger E, Sawchuk A \& Miyamoto R. Carotid body tumors, inheritance, and a high incidence of associated cervical paragangliomas. American Journal of Surgery $1996 \mathbf{1 7 2}$ 196-199. (doi:10.1016/S0002-9610(96)00151-1)

21 Netterville JL, Jackson CG, Miller FR, Wanamaker JR \& Glasscock ME. Vagal paraganglioma: a review of 46 patients treated during a 20-year period. Archives of Otolaryngology - Head \& Neck Surgery 1998124 1133-1140. (doi:10.1001/archotol.124.10.1133)

22 Jackson CG. Glomus tympanicum and glomus jugulare tumors. Otolaryngologic Clinics of North America 200134 941-970 (vii). (doi:10.1016/S0030-6665(05)70356-X) 
23 Lenders JW, Eisenhofer G, Armando I, Keiser HR, Goldstein DS \& Kopin IJ. Determination of metanephrines in plasma by liquid chromatography with electrochemical detection. Clinical Chemistry 199339 97-103.

24 Lenders JW, Pacak K, Walther MM, Linehan WM, Mannelli M, Friberg P, Keiser HR, Goldstein DS \& Eisenhofer G. Biochemical diagnosis of pheochromocytoma: which test is best? Journal of the American Medical Association 2002287 1427-1434.

25 Van Berkel A, Lenders JW \& Timmers HJ. Biochemical diagnosis of phaeochromocytoma and paraganglioma. European Journal of Endocrinology 2014170 R109-R119. (doi:10.1530/EJE-13-0882)

26 Lenders JW, Duh QY, Eisenhofer G, Gimenez-Roqueplo AP, Grebe SK, Murad MH, Naruse M, Pacak K \& Young WF Jr. Pheochromocytoma and paraganglioma: an endocrine society clinical practice guideline. Journal of Clinical Endocrinology and Metabolism 201499 1915-1942. (doi:10.1210/jc.2014-1498)

27 Eisenhofer G, Goldstein DS, Sullivan P, Csako G, Brouwers FM, Lai EW, Adams KT \& Pacak K. Biochemical and clinical manifestations of dopamine-producing paragangliomas: utility of plasma methoxytyramine. Journal of Clinical Endocrinology and Metabolism 200590 2068-2075. (doi:10.1210/jc.2004-2025)

28 Pacak K. Preoperative management of the pheochromocytoma patient. Journal of Clinical Endocrinology and Metabolism 200792 4069-4079. (doi:10.1210/jc.2007-1720)

29 de Jong WH, Eisenhofer G, Post JW, Muskiet FA, de Vries EG \& Kema IP. Dietary influences on plasma and urinary metanephrines: implications for the diagnosis of catecholamine-producing tumors. Journal of Clinical Endocrinology and Metabolism 200994 2841-2849. (doi:10.1210/jc.2009-0303)

30 Eisenhofer G, Goldstein DS, Walther MM, Friberg P, Lenders JW, Keiser HR \& Pacak K. Biochemical diagnosis of pheochromocytoma: how to distinguish true- from false-positive test results. Journal of Clinical Endocrinology and Metabolism 200388 2656-2666. (doi:10.1210/jc.2002-030005)

31 Brouwers FM, Eisenhofer G, Tao JJ, Kant JA, Adams KT, Linehan WM \& Pacak K. High frequency of SDHB germline mutations in patients with malignant catecholamine-producing paragangliomas: implications for genetic testing. Journal of Clinical Endocrinology and Metabolism 200691 4505-4509. (doi:10.1210/jc.2006-0423)

32 van der Harst E, de Herder WW, de Krijger RR, Bruining HA, Bonjer HJ, Lamberts SW, van den Meiracker AH, Stijnen TH \& Boomsma F. The value of plasma markers for the clinical behaviour of phaeochromocytomas. European Journal of Endocrinology 2002147 85-94. (doi:10.1530/eje.0.1470085)

33 Montesinos MS, MachadoJD, Camacho M, DiazJ, Morales YG, Alvarez de la Rosa D, Carmona E, Castañeyra A, Viveros OH, O'Connor DT et al. The crucial role of chromogranins in storage and exocytosis revealed using chromaffin cells from chromogranin A null mouse. Journal of Neuroscience 200828 3350-3358. (doi:10.1523/JNEUROSCI.5292-07.2008)

34 Rao F, keiser HR \& OÇonnor DT. Malignant pheochromocytoma. Chromaffin granule transmitters and response to treatment. Hypertension 200036 1045-1052. (doi:10.1161/01.HYP.36.6.1045)

35 d'Herbomez M, Gouze V, Huglo D, Nocaudie M, Pattou F, Proye C, Wémeau JL \& Marchandise X. Chromogranin A assay and (131)IMIBG scintigraphy for diagnosis and follow-up of pheochromocytoma. Journal of Nuclear Medicine 200142 993-997.

36 Algeciras-Schimnich A, Preissner CM, Young WF Jr, Singh RJ \& Grebe SK. Plasma chromogranin A or urine fractionated metanephrines follow-up testing improves the diagnostic accuracy of plasma fractionated metanephrines for pheochromocytoma. Journal of Clinical Endocrinology and Metabolism 200893 91-95. (doi:10.1210/jc.2007-1354)

37 Ilias I \& Pacak K. Current approaches and recommended algorithm for the diagnostic localization of pheochromocytoma. Journal of Clinical Endocrinology and Metabolism 200489 479-491. (doi:10.1210/jc. 2003-031091)
38 Maurea S, Cuocolo A, Reynolds JC, Neumann RD \& Salvatore M. Diagnostic imaging in patients with paragangliomas. Computed tomography, magnetic resonance and MIBG scintigraphy comparison. Quarterly Journal of Nuclear Medicine 199640 365-371.

39 Sohaib SA, Bomanji J, Evanson J \& Reznek RH. Imaging of the endocrine system. In Diagnostic Radiology: A Textbook of Medical Imaging, 4th edn, pp 1367-1399. Eds R Grainger, D Allison, A Adam \& A Dixon. London: Churchill Livingston, 2001.

40 Fink IJ, Reinig JW, Dwyer AJ, Doppman JL, Linehan WM \& Keiser HR. MR imaging of pheochromocytomas. Journal of Computer Assisted Tomography 19859 454-458. (doi:10.1097/00004728-19850500000006)

41 Shulkin BL, Ilias I, Sisson JC \& Pacak K. Current trends in functional imaging of pheochromocytomas and paragangliomas. Annals of the New York Academy of Sciences 20061073 374-382. (doi:10.1196/ annals.1353.041)

42 Bhatia KS, Ismail MM, Sahdev A, Rockall AG, Hogart K, Canizales A, Avril N, Monson JP, Grossman AB \& Reznek RH. ${ }^{123}$ I-metaiodobenzylguanidine (MIBG) scintigraphy for the detection of adrenal and extraadrenal phaeochromocytomas: CT and MRI correlation. Clinical Endocrinology 200869 181-188. (doi:10.1111/j.1365-2265.2008. 03256.x)

43 Wiseman GA, Pacak K, O'Dorisio MS, Neumann DR, Waxman AD, Mankoff DA, Heiba SI, Serafini AN, Tumeh SS, Khutoryansky N et al. Usefulness of ${ }^{123}$ I-MIBG scintigraphy in the evaluation of patients with known or suspected primary or metastatic pheochromocytoma or paraganglioma: result from a prospective multicenter trial. Journal of Nuclear Medicine 200950 1448-1454. (doi:10.2967/jnumed. 108.058701)

44 Milardovic R, Corssmit EP \& Stokkel M. Value of ${ }^{123}$ I-MIBG scintigraphy in paraganglioma. Neuroendocrinology 201091 94-100. (doi:10.1159/000242499)

45 Nielsen JT, Nielsen BV \& Rehling M. Location of adrenal medullary pheochromocytoma by I-123 metaiodobenzylguanidine SPECT. Clinical Nuclear Medicine 199621 695-699. (doi:10.1097/ 00003072-199609000-00005)

46 van der Harst E, de Herder WW, Bruining HA, Bonjer HJ, de Krijger RR, Lamberts SW, van de Meiracker AH, Boomsma F, Stijnen T, Krenning EP et al. [(123)I]metaiodobenzylguanidine and [(111)In]octreotide uptake in benign and malignant pheochromocytomas. Journal of Clinical Endocrinology and Metabolism 200186 685-693.

47 Ilias I, Chen CC, Carraquillo JA, Whatley M, Ling A, Lazurova I, Adams KT, Perera S \& Pacak K. Comparison of $6-{ }^{18} \mathrm{~F}$-fluorodopamine PET with ${ }^{123}$ I-metaiodobenzylguanidine and ${ }^{111}$ In-pentreotide scintigraphy in localization of nonmetastatic and metastatic pheochromocytoma. Journal of Nuclear Medicine 200849 1613-1619. (doi:10.2967/jnumed.108.052373)

48 Hoegerle S \& Nitzsche E. Pheochromocytomas: detection with ${ }^{18} \mathrm{~F}$ DOPA whole body PET-initial results. Radiology 2002222 507-512. (doi:10.1148/radiol.2222010622)

49 Timmers HJ, Kozupa A, Chen CC, Carrasquillo JA, Ling A, Eisenhofer G, Adams KT, Solis D, Lenders JW \& Pacak K. Superiority of fluorodeoxyglucose positron emission tomography to other functional imaging techniques in the evaluation of metastatic SDHBassociated pheochromocytoma and paraganglioma. Journal of Clinical Oncology 200725 2262-2269. (doi:10.1200/JCO.2006.09.6297)

50 Timmers HJ, Chen CC, Carrasquillo JA, Whatley M, Ling A, Havekes B, Eisenhofer G, Martiniova L, Adams KT \& Pacak K. Comparison of ${ }^{18} \mathrm{~F}$-fluoro-L-DOPA, ${ }^{18} \mathrm{~F}$-fluoro-deoxyglucose, and ${ }^{18} \mathrm{~F}$-fluorodopamine PET and ${ }^{123}$ I-MIBG scintigraphy in the localization of pheochromocytoma and paraganglioma. Journal of Clinical Endocrinology and Metabolism 200994 4757-4767. (doi:10.1210/jc.2009-1248)

51 van den Berg R, Verbist BM, Mertens BJ, van der Mey AG \& van Buchem MA. Head and neck paragangliomas: improved tumor detection using contrast-enhanced 3D time-of-flight MR angiography 
as compared with fat-suppressed MR imaging techniques. American Journal of Neuroradiology 200425 863-870.

52 Olsen WL, Dillon WP, Kelly WM, Norman D, Brant-Zawadzki M \& Newton TH. MR imaging of paragangliomas. American Journal of Roentgenology 1987148 201-204. (doi:10.2214/ajr.148.1.201)

53 Gritzmann N, Herold C, Haller J, Karnel F \& Schwaighofer B. Duplex sonography of tumors of the carotid body. Cardiovascular and Interventional Radiology 198710 280-284. (doi:10.1007/BF02578010)

54 Janetschek G, Finkenstedt G, Gasser R, Waibel UG, Peschel R, Bartsch G \& Neumann HP. Laparoscopic surgery for pheochromocytoma: adrenalectomy, partial resection, excision of paragangliomas. Journal of Urology 1998160 330-334. (doi:10.1016/S00225347(01)62886-6)

55 Pacak K, Eisenhofer G, Ahlman H, Bornstein SR, GimenezRoqueplo AP, Grossman AB, Kimura N, Mannelli M, McNicol AM \& Tischler AS. Pheochromocytoma: recommendations for clinical practice from the First International Symposium. October 2005. Nature Clinical Practice. Endocrinology \& Metabolism 20073 92-102. (doi:10.1038/ncpendmet0396)

56 Niemann U, Hiller W \& Behrend M. 25 years experience of the surgical treatment of phaeochromocytoma. European Journal of Surgery 2002 168 716-719. (doi:10.1080/00000000000000009)

57 Diner EK, Franks ME, Behari A, Linehan WM \& Walther MM. Partial adrenalectomy: the National Cancer Institute experience. Urology 200566 19-23. (doi:10.1016/j.urology.2005.01.009)

58 Buhl T, Mortensen J \& Kjaer A. I-123 MIBG imaging and intraoperative localization of metastatic pheochromocytoma: a case report. Clinical Nuclear Medicine 200227 183-185. (doi:10.1097/00003072200203000-00007)

59 van Hulsteijn LT, Corssmit EP, van der Hiel B, Smit JW \& Stokkel MP. Is there a role for radioguided surgery with iodine-labeled metaiodobenzylguanidine in resection of neuroendocrine tumors? Clinical Nuclear Medicine 201237 1083-1088. (doi:10.1097/RLU. 0b013e318266cb3d)

60 Lim JY, Kim J, Kim SH, Lee S, Lim YC, Kim JW \& Choi EC. Surgical treatment of carotid body paragangliomas: outcomes and complications according to the Shamblin classification. Clinical and Experimental Otorhinolaryngology 20103 91-95. (doi:10.3342/ceo.2010. 3.2.91)

61 Anand VK, Alemar GO \& Sanders TS. Management of the internal carotid artery during carotid body tumor surgery. Laryngoscope 1995 105 231-235. (doi:10.1288/00005537-199503000-00001)

62 Bradshaw JW \& Jansen JC. Management of vagal paraganglioma: is operative resection really the best option? Surgery 2005137 225-228. (doi:10.1016/j.surg.2004.09.009)

63 Luna-Ortiz K, Rascon-Ortiz M, Villavicencio-Valencia V, Granados-Garcia M \& Herrera-Gomez A. Carotid body tumors: review of a 20-year experience. Oral Oncology 200541 56-61. (doi:10.1016/j.oraloncology.2004.06.006)

64 van der Mey AG, Frijns JH, Brons EN, van Dulken H, Terpstra HL \& Schmidt PH. Does intervention improve the natural course of glomus tumors? a series of 108 patients seen in a 32-year period Annals of Otology, Rhinology, and Laryngology 1992101 635-642.

65 Cole JM \& Beiler D. Long-term results of treatment for glomus jugulare and glomus vagale tumors with radiotherapy. Laryngoscope 1994104 1461-1465.

66 van Houtum WH, Corssmit EP, Douwes Dekker PB, Jansen JC, van der Mey AG, Bröcker-Vriends AH, Taschner PE, Losekoot M, Frölich M, Stokkel MP et al. Increased prevalence of catecholamine excess and phaeochromocytomas in a well-defined Dutch population with SDHD-linked head and neck paragangliomas. European Journal of Endocrinology 2005152 87-94. (doi:10.1530/eje.1.01833)

67 Power AM, Bower TC, Kasperbauer J, Link MJ, Oderich G, Cloft H, Young WF \& Gloviczki P. Impact of preoperative embolization on outcomes of carotid body tumour resection. Journal of Vascular Surgery 201256 979-989. (doi:10.1016/j.jvs.2012.03.037)
68 van Hulsteijn LT, Corssmit EP, Coremans IE, Smit JW, Jansen JC \& Dekkers OM. Regression and local control rates after radiotherapy for jugulotympanic paragangliomas: systematic review and meta-analysis. Radiotherapy and Oncology 2013106 161-168. (doi:10. 1016/j.radonc.2012.11.002)

69 Boedeker CC, Ridder GJ \& Schipper J. Paragangliomas of the head and neck: diagnosis and treatment. Familial Cancer 20054 55-59. (doi:10.1007/s10689-004-2154-z)

70 Persky MS, Setton A, Niimi Y, Hartman J, Frank D \& Berenstein A. Combined endovascular and surgical treatment of head and neck paragangliomas - a team approach. Head \& Neck 200224 423-431. (doi:10.1002/hed.10068)

71 Chrisoulidou A, Kaltsas G, Ilias I \& Grossman AB. The diagnosis and management of malignant phaeochromocytoma and paraganglioma. Endocrine-Related Cancer 2007 14 569-585. (doi:10.1677/ERC-07-0074)

72 Lee JH, Barich F, Karnell LH, Robinson RA, Zhen WK, Gantz BJ \& Hoffman HT. National Cancer Data Base report on malignant paragangliomas of the head and neck. Cancer 200294 730-737. (doi:10.1002/cncr.10252)

73 Boedeker CC, Neumann HP, Maier W, Bausch B, Schipper J \& Ridder GJ. Malignant head and neck paragangliomas in SDHB mutation carriers. Otolaryngology - Head and Neck Surgery 2007137 126-129. (doi:10.1016/j.otohns.2007.01.015)

74 Burnichon N, Rohmer V, Amar L, Herman P, Leboulleux S, Darrouzet V, Niccoli P, Gaillard D, Chabrier G, Chabolle F et al. The succinate dehydrogenase genetic testing in a large prospective series of patients with paragangliomas. Journal of Clinical Endocrinology and Metabolism 200994 2817-2827. (doi:10.1210/jc.2008-2504)

75 Neumann HP, Pawlu C, Peczkowska M, Bausch B, McWhinney SR, Muresan M, Buchta M, Franke G, Klisch J, Bley TA et al. Distinct clinical features of paraganglioma syndromes associated with SDHB and SDHD gene mutations. Journal of the American Medical Association 2004292 943-951. (doi:10.1001/jama.292.8.943)

76 Benn DE, Gimenez-Roqueplo AP, Reilly JR, Bertherat J, Burgess J, Byth K, Croxson M, Dahia PL, Elston M, Gimm O et al. Clinical presentation and penetrance of pheochromocytoma/paraganglioma syndromes. Journal of Clinical Endocrinology and Metabolism 200691 827-836. (doi:10.1210/jc.2005-1862)

77 Havekes B, Corssmit EP, Jansen JC, van der Mey AG, Vriends AH \& Romijn JA. Malignant paragangliomas associated with mutations in the succinate dehydrogenase D gene. Journal of Clinical Endocrinology and Metabolism 200792 1245-1248. (doi:10.1210/ jc.2006-1993)

78 Comino-Méndez I, Gracia-Aznárez FJ, Schiavi F, Landa I, LeandroGarcía LJ, Letón R, Honrado E, Ramos-Medina R, Caronia D, Pita G et al. Exome sequencing identifies MAX mutations as a cause of hereditary pheochromocytoma. Nature Genetics 201143 663-667. (doi:10.1038/ng.861)

79 Welander J, Soderkvist P \& Gimm O. Genetics and clinical characteristics of hereditary pheochromocytomas and paragangliomas. Endocrine-Related Cancer 201118 R253-R276. (doi:10.1530/ ERC-11-0170)

80 Pacak K, Ilias I, Adams KT \& Eisenhofer G. Biochemical diagnosis, localization and management of pheochromocytoma: focus on multiple endocrine neoplasia type 2 in relation to other hereditary syndromes and sporadic forms of the tumour. Journal of Internal Medicine 2005257 60-68. (doi:10.1111/j.1365-2796.2004.01425.x)

81 Mukherjee JJ, Kaltsas GA, Islam N, Plowman PN, Foley R, Hikmat J, Britton KE, Jenkins PJ, Chew SL, Monson JP et al. Treatment of metastatic carcinoid tumours, phaeochromocytoma, paraganglioma and medullary carcinoma of the thyroid with (131)I-meta-iodobenzylguanidine [(131)I-MIBG]. Clinical Endocrinology 200155 47-60. (doi:10.1046/j.1365-2265.2001.01309.x)

82 Hescot S, Leboulleux S, Amar L, Vezzosi D, Borget I, Bournaud-Salinas C, de la Fouchardiere C, Libé R, Do Cao C, Niccoli P et al. One-year progression-free survival of therapy-naive patients with 
malignant pheochromocytoma and paraganglioma. Journal of Clinical Endocrinology and Metabolism 201310 4006-4012. (doi:10.1210/jc. 2013-1907)

83 van Hulsteijn LT, Niemeijer ND, Dekkers OM \& Corssmit EP. ${ }^{131}$ I-MIBG therapy for malignant paraganglioma and pheochromocytoma: systematic review and meta-analysis. Clinical Endocrinology 201480 487-501. (doi:10.1111/cen.12341)

84 Huang H, Abraham J, Hung E, Averbuch S, Merino M, Steinberg SM, Pacak K \& Fojo T. Treatment of malignant pheochromocytoma/ paraganglioma with cyclophosphamide, vincristine, and dacarbazine: recommendation from a 22-year follow-up of 18 patients. Cancer 2008 113 2020-2028. (doi:10.1002/cncr.23812)

85 Keiser HR, Goldstein DS, Wade JL, Douglas FL \& Averbuch SD. Treatment of malignant pheochromocytoma with combination chemotherapy. Hypertension 19857 I18-I24. (doi:10.1161/01.HYP.7. 3_Pt_2.I18)

86 Forrer F, Riedweg I, Maecke HR \& Mueller-Brand J. Radiolabeled DOTATOC in patients with advanced paraganglioma and pheochromocytoma. Quarterly Journal of Nuclear Medicine and Molecular Imaging 200852 334-340.

87 Joshua AM, Ezzat S, Asa SL, Evans A, Broom R, Freeman M \& Knox JJ. Rationale and evidence for sunitinib in the treatment of malignant paraganglioma/ pheochromocytoma. Journal of Clinical Endocrinology and Metabolism 200994 5-9. (doi:10.1210/jc.2008-1836)

88 Maithel SK \& Fong Y. Hepatic ablation for neuroendocrine tumor metastases. Journal of Surgical Oncology 2009100 635-638. (doi:10.1002/jso.21196)

89 Takahashi K, Ashizawa N, Minami T, Suzuki S, Sakamoto I, Hayashi K, Tomiyasu S, Sumikawa K, Kitamura K, Eto T et al. Malignant pheochromocytoma with multiple hepatic metastases treated by chemotherapy and transcatheter arterial embolization. Internal Medicine 199938 349-354. (doi:10.2169/internalmedicine.38.349)

90 Scholz T, Eisenhofer G, Pacak K, Dralle H \& Lehnert H. Clinical review: Current treatment of malignant pheochromocytoma. Journal of Clinical Endocrinology and Metabolism 200792 1217-1225. (doi:10.1210/jc.2006-1544)

91 Edstrom EE, Hjelm Skog AL, Hoog A \& Hamberger B. The management of benign and malignant pheochromocytoma and abdominal paraganglioma. European Journal of Surgical Oncology 200329 278-283. (doi:10.1053/ejso.2002.1413)

92 Neumann HP, Erlic Z, Boedeker CC, Rybicki LA, Robledo M, Hermsen M, Schiavi F, Falcioni M, Kwok P, Bauters C et al. Clinical predictors for germline mutations in head and neck paraganglioma patients: cost reduction strategy in genetic diagnostic process as fallout. Cancer Research 200969 3650-3656. (doi:10.1158/0008-5472. CAN-08-4057)

93 Latif F, Tory K, Gnarra J, Yao M, Duh FM, Orcutt ML, Stackhouse T, Kuzmin I, Modi W, Geil L et al. Identification of the von HippelLindau disease tumor suppressor gene. Science 1993260 1317-1320. (doi:10.1126/science.8493574)

94 Eng C. Seminars in medicine of the Beth Israel Hospital, Boston. The RET proto-oncogene in multiple endocrine neoplasia type 2 and Hirschsprung's disease. New England Journal of Medicine 1996335 943-951. (doi:10.1056/NEJM199609263351307)

95 Neumann HP, Berger DP, Sigmund G, Blum U, Schmidt D, Parmer RJ, Volk B \& Kirste G. Pheochromocytomas, multiple endocrine neoplasia type 2, and von Hippel-Lindau disease. New England Journal of Medicine 1993329 1531-1538. (doi:10.1056/NEJM199311183292103)

96 White R \& O'Connell P. Identification and characterization of the gene for neurofibromatosis type 1. Current Opinion in Genetics \& Development 19911 15-19. (doi:10.1016/0959-437X(91)80034-J)

97 Neumann HP, Bausch B, McWhinney SR, Bender BU, Gimm O, Franke G, Schipper J, Klisch J, Altehoefer C, Zerres K et al. Germ-line mutations in nonsyndromic pheochromocytoma. New England Journal of Medicine 2002346 1459-1466. (doi:10.1056/ NEJMoa020152)
98 Astuti D, Latif F, Dallol A, Dahia PL, Douglas F, George E, Sköldberg F, Husebye ES, Eng C \& Maher ER. Gene mutations in the succinate dehydrogenase subunit SDHB cause susceptibility to familial pheochromocytoma and to familial paraganglioma. American Journal of Human Genetics 200169 49-54. (doi:10.1086/321282)

99 Baysal BE, Ferrell RE, Willett-Brozick JE, Lawrence EC, Myssiorek D, Bosch A, van der Mey A, Taschner PE, Rubinstein WS, Myers EN et al. Mutations in SDHD, a mitochondrial complex II gene, in hereditary paraganglioma. Science 2000287 848-851. (doi:10.1126/science.287. 5454.848)

100 Burnichon N, Brière JJ, Libé R, Vescovo L, Rivière J, Tissier F, Jouanno E, Jeunemaitre X, Bénit P, Tzagoloff A et al. SDHA is a tumor suppressor gene causing paraganglioma. Human Molecular Genetics 201019 3011-3020. (doi:10.1093/hmg/ddq206)

101 Niemann S \& Muller U. Mutations in SDHC cause autosomal dominant paraganglioma, type 3. Nature Genetics 200026 268-270. (doi:10.1038/81551)

102 Hao HX, Khalimonchuk O, Schraders M, Dephoure N, Bayley JP, Kunst H, Devilee P, Cremers CW, Schiffman JD, Bentz BG et al. SDH5, a gene required for flavination of succinate dehydrogenase, is mutated in paraganglioma. Science 2009325 1139-1142. (doi:10.1126/science. 1175689)

103 Qin Y, Yao L, King EE, Buddavarapu K, Lenci RE, Chocron ES, Lechleiter JD, Sass M, Aronin N, Schiavi F et al. Germline mutations in TMEM127 confer susceptibility to pheochromocytoma. Nature Genetics 201042 229-233. (doi:10.1038/ng.533)

104 Castro-Vega LJ, Buffet A, De Cubas AA, Cascón A, Menara M, Khalifa E, Amar L, Azriel S, Bourdeau I, Chabre O et al. Germline mutations in FH confer predisposition to malignant pheochromocytomas and paragangliomas. Human Molecular Genetics 201423 2440-2446. (doi:10.1093/hmg/ddt639)

105 van Hulsteijn LT, Dekkers OM, Hes FJ, Smit JW \& Corssmit EP. Risk of malignant paraganglioma in SDHB-mutation and SDHD-mutation carriers: a systematic review and meta-analysis. Journal of Medical Genetics 201249 768-776. (doi:10.1136/jmedgenet-2012-101192)

106 Lee S, Nakamura E, Yang H, Wei W, Linggi MS, Sajan MP, Farese RV, Freman RS, Carter BD, Kaelin WG Jr et al. Neuronal apoptosis is linked to EgIN3 prolyl hydroxylase and familial pheochromocytoma genes: developmental cullin and cancer. Cancer Cell 20058 155-167. (doi:10.1016/j.ccr.2005.06.015)

107 Ladroue C, Carcenac R, Leporrier M, Gad S, Le Hello C, GalateauSalle F, Feunteun J, Pouyssegur J, Richard S \& Gardie B. PHD2 mutation and congenital erythrocytosis with paraganglioma. New England Journal of Medicine 2008359 2685-2692. (doi:10.1056/ NEJMoa0806277)

108 Gaal J, Burnichon N, Korpershoek E, Roncelin I, Bertherat J, Plouin PF, de Krijger RR, Gimenez-Roqueplo AP \& Dinjens WN. Isocitrate dehydrogenase mutations are rare in pheochromocytomas and paragangliomas. Journal of Clinical Endocrinology and Metabolism 2010 95 1274-1278. (doi:10.1210/jc.2009-2170)

109 Zhuang Z, Yang C, Lorenzo F, Merino M, Fojo T, Kebebew E, Popovic V, Stratakis CA, Prchai JT \& Pacak K. Somatic HIF2A gain-of-function mutations in paraganglioma with polycythemia. New England Journal of Medicine 2012367 922-930. (doi:10.1056/ NEJMoa1205119)

110 Carney JA \& Stratakis CA. Familial paraganglioma and gastric stromal sarcoma: a new syndrome distinct from the Carney triad. American Journal of Medical Genetics 2002108 132-139. (doi:10.1002/ajmg.10235)

111 McWhinney SR, Pasini B \& Stratakis CA. Familial gastrointestinal stromal tumors and germ-line mutations. New England Journal of Medicine 2007357 1054-1056. (doi:10.1056/NEJMc071191)

112 Vanharanta S, Buchta M, McWhinney SR, Virta SK, Peçzkowska M, Morrison CD, Lehtonen R, Januszewicz A, Järvinen $\mathrm{H}$, Juhola $\mathrm{M}$ et al. Early-onset renal cell carcinoma as a novel extraparaganglial component of SDHB-associated heritable paraganglioma. American Journal of Human Genetics $2004 \mathbf{7 4}$ 153-159. (doi:10.1086/381054) 
113 Xekouki P, Pacak K, Almeida M, Wassif CA, Rustin P, Nesterova M, de la Luz Sierra M, Matro J, Ball E, Azevedo M et al. Succinate dehydrogenase (SDH) D subunit (SDHD) inactivation in a growthhormone-producing pituitary tumor: a new association for SDH? Journal of Clinical Endocrinology and Metabolism 201297 E357-E366. (doi:10.1210/jc.2011-1179)

114 Dahia PL, Ross KN, Wright ME, Hayashida CY, Santagata S, Barontini M, Kung AL, Sanso G, Powers JF, Tischler AS et al. A HIF1 $\alpha$ regulatory loop links hypoxia and mitochondrial signals in pheochromocytomas. PLoS Genetics 2005 172-80. (doi:10.1371/journal. pgen.0010008)

115 Favier J, Brière JJ, Burnichon N, Rivière J, Vescovo L, Benit P, GiscosDouriez I, De Reyniès A, Bertherat J, Badoual C et al. The Warburg effect is genetically determined in inherited pheochromocytomas. PLoS ONE 20094 e7094. (doi:10.1371/journal.pone.0007094)

116 Favier J \& Gimenez-Roqueplo AP. Pheochromocytomas: the (pseudo)hypoxia hypothesis. Best Practice \& Research. Clinical Endocrinology \& Metabolism 201024 957-968. (doi:10.1016/j.beem.2010.10.004)

117 Qin Y, Buddavarapu K \& Dahia PL. Pheochromocytomas: from genetic diversity to new paradigms. Hormone and Metabolic Research 200941 664-671. (doi:10.1055/s-0029-1215590)

118 Letouzé E, Martinelli C, Loriot C, Burnichon N, Abermil N, Ottolenghi C, Janin M, Menara M, Nguyen AT, Benit P et al. SDH mutations establish a hypermethylator phenotype in paraganglioma. Cancer Cell 201323 739-752. (doi:10.1016/j.ccr.2013.04.018)

119 Califano D, Rizzo C, D'Alessio A, Colucci-D'Amato GL, Cali G, Bartoli PC, Santelli G, Vecchio G \& de Franciscis V. Signaling through Ras is essential for ret oncogene-induced cell differentiation in PC12 cells. Journal of Biological Chemistry 2000275 19297-19305. (doi:10.1074/jbc.M905866199)

120 Johannessen CM, Reczek EE, James MF, Brems H, Legius E \& Cichowski K. The NF1 tumor suppressor critically regulates TSC2 and mTOR. PNAS 2005102 8573-8578. (doi:10.1073/pnas.0503224102)

121 Martin GA, Viskoohil D, Bollag G, McCabe PC, Crosier WJ, Haubruck H, Conroy L, Clark R, O'Connell P, Cawthon RM et al. The GAP-related domain of the neurofibromatosis type 1 gene product interacts with ras p21. Cell 199063 843-849. (doi:10.1016/00928674(90)90150-D)

122 Johannessen CM, Johnson BW, Williams SM, Chan AW, Reczek EE, Lynch RC, Rioth MJ, McClatchey A, Ryeom S \& Cichowski K. TORC1 is essential for NF1-associated malignancies. Current Biology 200818 56-62. (doi:10.1016/j.cub.2007.11.066)

123 Baysal BE, Farr JE, Rubinstein WS, Galus RA, Johnson KA, Aston CE, Myers EN, Johnson JT, Carrau R, Kirkpatrick SJ et al. Fine mapping of an imprinted gene for familial nonchromaffin paragangliomas, on chromosome 11q23. American Journal of Human Genetics 199760 121-132.

124 Heutink P, van der Mey AG, Sandkuijl LA, van Gils AP, Bardoel A, Breedveld GJ, van Vliet M, van Ommen GJ, Cornelisse CJ, Oostra BA et al. A gene subject to genomic imprinting and responsible for hereditary paragangliomas maps to chromosome 11q23-qter. Human Molecular Genetics 19921 7-10. (doi:10.1093/hmg/1.1.7)

125 van der Mey AG, Maaswinkel-Mooy PD, Cornelisse CJ, Schmidt PH \& van de Kamp JJ. Genomic imprinting in hereditary glomus tumours: evidence for new genetic theory. Lancet 19892 1291-1294. (doi:10.1016/S0140-6736(89)91908-9)

126 Hensen EF, Jordanova ES, van Minderhout IJ, Hogendoorn PC, Taschner PE, van der Mey AG, Devilee P \& Cornelisse CJ. Somatic loss of maternal chromosome 11 causes parent-of-origin-dependent inheritance in SDHD-linked paraganglioma and phaeochromocytoma families. Oncogene 200423 4076-4083. (doi:10.1038/sj.onc.1207591)
127 Hes FJ, Weiss MM, Woortman SA, de Miranda NF, van Bunderen PA, Bonsing BA, Stokkel MP, Morreau H, Romijn JA, Jansen JC et al. Low penetrance of a SDHB mutation in a large Dutch paraganglioma family. BMC Medical Genetics 201011 92. (doi:10.1186/1471-2350-11-92)

128 Gimenez-Roqueplo AP, Lehnert H, Mannelli M, Neumann H, Opocher G, Maher ER \& Plouin PF. Phaeochromocytoma, new genes and screening strategies. Clinical Endocrinology 200665 699-705. (doi:10.1111/j.1365-2265.2006.02714.x)

129 Gill AJ, Benn DE, Chou A, Clarkson A, Muljono A, Meyer-Rochow GY, Richardson AL, Sidhu SB, Robinson BG \& Clifton-Bligh RJ. Immunohistochemistry for SDHB triages genetic testing of SDHB, SDHC, and SDHD in paraganglioma-pheochromocytoma syndromes. Human Pathology 201041 805-814. (doi:10.1016/j.humpath.2009.12.005)

130 van Nederveen FH, Gaal J, Favier J, Korpershoek E, Oldenburg RA, de Bruyn EM, Sleddens HF, Derkx P, Rivière J, Dannenberg H et al. An immunohistochemical procedure to detect patients with paraganglioma and phaeochromocytoma with germline SDHB, SDHC, or SDHD gene mutations: a retrospective and prospective analysis. Lancet Oncology 200910 764-771. (doi:10.1016/S1470-2045(09)70164-0)

131 Bayley JP, Weiss MM, Grimbergen A, van Brussel BT, Hes FJ, Jansen JC, Verhoef S, Devilee P, Corssmit EP \& Vriends AH. Molecular characterization of novel germline deletions affecting SDHD and SDHC in pheochromocytoma and paraganglioma patients. EndocrineRelated Cancer 200916 929-937. (doi:10.1677/ERC-09-0084)

132 Rattenberry E, Vialard L, Yeung A, Bair H, McKay K, Jafri M, Canham N, Cole TR, Denes J, Hodgson SV et al. A comprehensive next generation sequencing-based genetic testing strategy to improve diagnosis of inherited pheochromocytoma and paraganglioma. Journal of Clinical Endocrinology and Metabolism 201398 1246-1256. (doi:10.1210/jc.2013-1319)

133 Toledo RA \& Dahia PL. Next-generation sequencing for the genetic screening of phaeochromocytomas and paragangliomas: riding the new wave, but with caution. Clinical Endocrinology 201480 23-24. (doi:10.1111/cen.12357)

134 van Gils AP, van der Mey AG, Hoogma RP, Sandkuijl LA, MaaswinkelMooy PD, Falke TH \& Pauwels EK. MRI screening of kindred at risk of developing paragangliomas: support for genomic imprinting in hereditary glomus tumours. British Journal of Cancer 199265 903-907. (doi:10.1038/bjc.1992.189)

135 Hermsen MA, Sevilla MA, Llorente JL, Weiss MM, Grimbergen A, Allonca E, Garcia-Inclán C, Balbín M \& Suárez C. Relevance of germline mutation screening in both familial and sporadic head and neck paraganglioma for early diagnosis and clinical management. Cellular Oncology 201032 275-283.

136 van Duinen N, Steenvoorden D, Bonsing BA, Vuyk J, Vriends AH, Jansen JC, Romijn JA \& Corssmit EP. Pheochromocytomas detected by biochemical screening in predisposed subjects are associated with lower prevalence of clinical and biochemical manifestations and smaller tumors than pheochromocytomas detected by signs and symptoms. European Journal of Endocrinology 2010163 121-127. (doi:10.1530/EJE-10-0114)

137 van Hulsteijn LT, Kaptein AA, Louisse A, Biermasz NR, Smit JW \& Corssmit EP. Illness perceptions, risk perception and worry in SDH mutation carriers. Familial Cancer 201413 83-91. (doi:10.1007/ s10689-013-9680-5)

138 Timmers HJ, Gimenez-Roqueplo AP, Mannelli M \& Pacak K. Clinical aspects of SDHx-related pheochromocytoma and paraganglioma. Endocrine-Related Cancer 200916 391-400. (doi:10.1677/ERC-08-0284)

Received 16 May 2014

Revised version received 2 July 2014

Accepted 24 July 2014 